\title{
Upaya Peningkatan Hasil Belajar Mata Pelajaran AI-Qur'an Hadits Melalui Penerapan Metode Advokasi
}

\author{
Haryanto $^{1 *}$ dan Suhartono $0^{2^{*}}$ \\ ${ }^{1}$ STKIP Nurul Huda OKU Timur \\ ${ }^{2}$ Dosen Prodi PAI STKIP Nurul Huda OKU Timur \\ "haryanto@gmail.com \\ *suhartono@stkipnurulhuda.ac.id
}

\begin{abstract}
Abstrak
Metode pembelajaran sebagai salah satu faktor penentu keberhasilan belajar siswa kurang mendapatkan perhatian dari para guru, pada proses pembelajaran guru hanya memberikan ringkasan materi dengan cara mendektekan kepada siswa kemudian guru menjelaskan materi tersebut secara oral tanpa memberikan feed back kepada siswa. Tujuan penelitian ini adalah untuk mengetahui ada tidaknya peningkatan hasil belajar mata pelajaran Al-Qur'an Hadits melalui penerapan metode Advokasi siswa kelas X IPA MA Nurul Huda Kecamatan Buay Madang Kabupaten OKU Timur. Penelitian dilaksanakan menggunakan desain penelitian tindakan kelas yang dilaksanakan dalam 3 siklus. Subjek dari penelitian ini adalah siswa kelas X IPA MA Nurul Huda yang berjumlah 27 siswa. Teknik pengumpulan data menggunakan observasi dan tes, sedangkan teknik analisa data menggunakan teknik holberman yaitu reduksi, penyajian dan penarikan kesimpulan. Kesimpulan penelitian ini pertama hasil belajar mata pelajaran Al-Qur'an Hadits materi pembelajaran pokok-pokok isi kitab Al-Qur'an siswa sebelum penerapan metode Advokasi di kelas X IPA MA Nurul Huda adalah sangat rendah. Kedua hasil belajar mata pelajaran Al-Qur'an Hadits materi pembelajaran pokok-pokok isi kitab Al-Qur'an siswa setelah penerapan metode Advokasi di kelas X IPA MA Nurul Huda termasuk kategori tinggi atau baik. Ketiga Penerapan metode Advokasi dapat meningkatkan hasil belajar mata ini dengan indikator aktivitas guru dalam pembelajaran termasuk kategori baik, aktivitas siswa dalam pembelajaran masuk kategori baik.
\end{abstract}

Kata kunci: Metode Advokasi, Hasil Belajar, AI-Qur'an Hadits.

\section{PENDAHULUAN}

Tujuan akhir Anda adalah untuk membuat makalah yang sesuai dengan aturan baku jurnal Al I'tibar. Untuk hal-hal yang tidak tercantum di panduan ini, silahkan mengacu pada informasi yang telah Anda dapatkan pada aturan penulisan ilmiah. Makalah dipersiapkan dalam bentuk softcopy dengan format ukuran kertas A4. Batas tepi: atas $=2,54 \mathrm{~cm}$, bawah $=2,54 \mathrm{~cm}$, sisi $=1,9 \mathrm{~cm}$. Ukuran paragraf menjorok adalah $0,35 \mathrm{~cm}$.

Allah SWT menurunkan Al-Qur'an kepada manusia dengan sebuah tujuan mendidik dan mengarahkan manusia agar berhasil menjalankan fungsi utama keberadaan mereka dimuka bumi sebagai khalifah Allah dan hamba-Nya. Seluruh potensi kecerdasan yang Allah SWT karuniakan untuk membangun peradaban kelak harus dipertanggung jawabkan, dan Al-Qur'an merupakan jawaban atas seluruh permasalahan tersebut. Hal tersebut sebagaimana dikemukakan Al-Maraghi (t.t.:267) sebagai berikut:

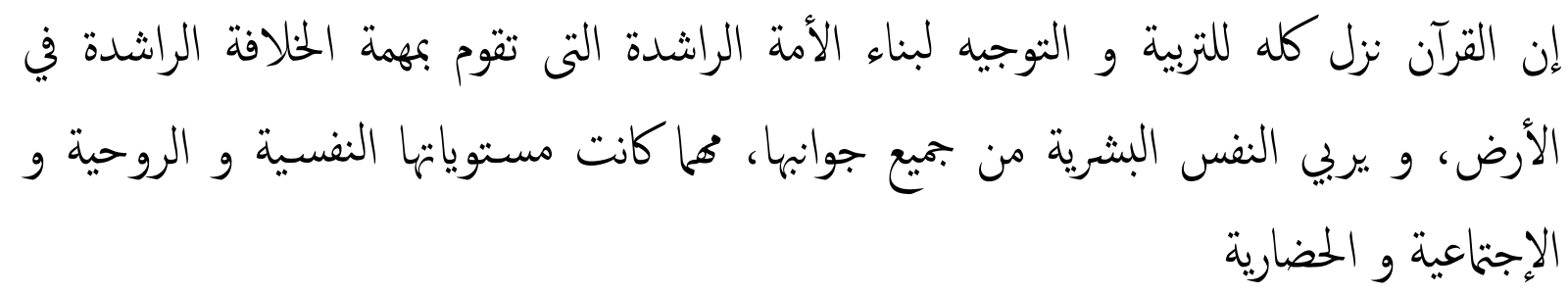

Artinya: Sesungguhnya Al-Qur'an seluruhnya berisi pendidikan dan pengarahan untuk membangun sebuah bangsa yang mulia yang tegak sebagai khilafah ar Rasyidah di dunia, dan 
mendidik jiwa kemanusiaan dalam seluruh aspeknya, sehingga terbangun integralitas manusia dalam aspek pribadi, spiritual, sosial dan peradaban.

Tujuan pembelajaran Al- Qur'an Hadits dijadikan sebagai dasar dalam pelaksanaan seluruh aktivitas pembelajaran Al- Qur'an Hadits yang dilaksanakan mulai tingkat sekolah dasar hingga di tingkat menengah atas. Ketercapaian tujuan pembelajaran Al- Qur'an Hadits sebagaimana pada pembelajaran lain sering disebut dengan hasil belajar. Berkaitan dengan hasil belajar, Thobroni (2011:22) mengatakan "Hasil belajar adalah pola-pola perbuatan, nilai-nilai, pengertian-pengertian, sikap-sikap, apresiasi dan keterampilan yang diperoleh individu setelah kegiatan belajar". Indikator yang dijadikan tolak ukur dalam menyatakan bahwa suatu proses belajar mengajar dikatakan berhasil, berdasarkan ketentuan kurikulum yang disempurnakan, dan yang saat ini digunakan adalah

1. Daya serap terhadap bahan pelajaran yang telah diajarkan mencapai prestasi tinggi, baik secara individu maupun kelompok.

2. Perilaku yang digariskan dalam tujuan pengajaran atau intruksional khusus (TIK) telah dicapai siswa baik secara individu maupun secara kelompok (Utsman, 1993:3).

Demikian dua macam tolak ukur yang dapat digunakan sebagai acuan dalam menentukan tingkat keberhasilan proses belajar mengajar. Namun yang banyak dijadikan sebagai tolak ukur keberhasilan dari keduanya ialah daya serap siswa terhadap pelajaran.

1. Tingkat keberhasilan

Setiap proses belajar-mengajar selalu menghasilkan hasil belajar, masalah yang dihadapi ialah sampai ditingkat mana prestasi (hasil) belajar yang telah dicapai, sehubungan dengan hal inilah keberhasilan belajar dibagi menjadi beberapa tingkatan atau taraf, antara lain sebagai berikut :

a. Istimewa/maksimal: apabila seluruh bahan pelajaran yang telah diajarkan dapat dikuasai siswa.

b. Baik sekali/optimal: apabila sebagian besar (76\% sd $99 \%)$ bahan pelajaran yang telah dipelajari dapat dikuasai siswa.

c. Baik/minimal: apabila bahan pelajaran yang telah diajarkan hanya (60\% sd $75 \%)$ dikuasai siswa.

d. Kurang: apabila bahan pelajaran yang telah diajarkakn kurang dari $60 \%$ yang dikuasai siswa (Djamarah, 1996:121).

2. Penilaian

Penilaian merupakan suatu proses kegiatan untuk memperoleh, menganalisis, dan menafsirkan data tentang proses dan hasil belajar siswa, kegiatan penilaian tersebut dimaksudkan untuk mengetahui kemampuan belajar siswa setiap waktu. Oleh sebab itu penilaian harus dilakukan secara sistematis dan berkesinambungan sehingga menjadi informasi yang bermakna dalam pengambilan keputusan (Rahim, 2005:74).

Pencapaian hasil belajar Al- Qur'an Hadits dipengaruhi oleh beberapa faktor sebagaimana faktor yang mempengaruhi belajar. Berkaitan dengan faktor yang mempengaruhi belajar, Slameto (2010:54) menjelaskan bahwa faktor yang mempengaruhi belajar dapat digolongkan menjadi dua golongan yaitu faktor intern dan faktor ekstern. Faktor intern adalah faktor dalam diri individu sedang belajar, sedangkan faktor ekstern adalah faktor di luar individu seperti penggunaan pendekatan maupun metode pembelajaran secara tepat.

Berdasarkan penjelasan tersebut diketahui bahwa metode pembelajaran merupakan salah satu faktor yang mempengaruhi belajar siswa yang akan berimplikasi pada tingkat ketercapaian hasil belajar. Metode pembelajaran sebagai salah satu faktor penentu keberhasilan belajar siswa 
kurang mendapatkan perhatian dari para guru. Umumnya guru menyampaikan materi pembelajaran hanya sekedar kejar target kurikulum. Hal tersebut sebagaimana terjadi pada pembelajaran Al- Qur'an Hadits kelas X IPA MA Nurul Huda kecamatan Buay Madang kabupaten OKU Timur. Berdasarkan hasil observasi pendahuluan pada hari Senin 20 November 2017 diketahui bahwa pembelajaran Al-Qur'an Hadits di kelas X IPA MA Nurul Huda dilakukan dengan menulis, diskusi dan mendengarkan guru menyampaikan materi.

Keadaan pembelajaran AI-Qur'an Hadits di kelas X IPA MA Nurul Huda sebagaimana tersebut mengakibatkan pemahaman siswa terbatas pada apa yang disampaikan guru melalui ceramah dan berimplikasi pada rendahnya ketuntasan hasil belajar siswa. Hal tersebut dibuktikan dari hasil dokumentasi nilai midle semester ganjil tahun pelajaran 2017/2018 yang menunjukkan dari 27 siswa hanya terdapat 7 siswa $(14,71 \%)$ yang mencapai ketuntasan dengan memperoleh nilai $>80$, sedangkan 20 siswa $(80,00 \%)$ belum mencapai ketuntasan dengan memperoleh nilai $<80$.

Uraian keadaan pembelajaran Al-Qur'an Hadits di kelas X IPA MA Nurul Huda sebagaimana tersebut menunjukkan adanya permasalahan dalam kegiatan pembelajaran. Setelah dilakukan identifikasi lebih lanjut diketahui bahwa penyebab dari kurang efektifnya kegiatan pembelajaran dan rendahnya hasil belajar Al-Qur'an Hadits di kelas X IPA MA Nurul Huda adalah karena sistem pembelajaran yang berpusat pada siswa melalui penerapan menulis, diskusi dan mendengarkan guru menyampaikan materi. Oleh karena itu, perlu diadakan perubahan metode pembelajaran AlQur'an Hadits di kelas X IPA MA Nurul Huda yang dalam hal ini melalui penerapan metode Advokasi.

Metode pembelajaran Advokasi merupakan pembelajaran yang berpusat pada siswa (student-centered advocacy learning) sering diidentikkan dengan proses debat. Utsman (2011:46) mengemukakan, "Metode pembelajaran Advokasi adalah metode pembelajaran yang mana mengajak siswa aktif dalam kegiatan pembelajaran sehingga diharapkan dengan menggunakan metode Advokasi dapat meningkatkan hasil belajar siswa". Pembelajaran Advokasi dipandang sebagai suatu pendekatan alternatif terhadap pengajaran didaktis di dalam kelas yang memberikan kesempatan kepada siswa untuk mempelajari isu-isu sosial dan personal melalui keterlibatan langsung dan partisipasi pribadi. Metode pembelajaran Advokasi menuntut para siswa terfokus pada topik yang telah ditentukan sebelumnya dan mengajukan pendapat yang bertalian dengan topik pembelajaran.

Menurut Huda (2013:117), metode pembelajaran Advokasi merupakan metode pembelajaran alternatif untuk meningkatkan proses belajar siswa yang memberikan kesempatan kepada siswa untuk menjadi Advokasi dari suatu pendapat tertentu yang bertalian dengan topik yang tersedia. Siswa menggunakan keterampilan riset, keterampilan analisis, dan keterampilan berbicara dan juga mendengar, sebagaimana mereka berpartisipasi dalam kelas pengalaman Advokasi. Siswa pada pembelajaran Advokasi dihadapkan dengan isu-isu kontroversial dan harus mengembangkan suatu kasus untuk mendukung pendapat mereka di dalam perangkat untuk tujuan-tujuan khusus. Hal ini menunjukkan bahwa metode pembelajaran Advokasi adalah metode pembelajaran yang mengajak siswa turut aktif dalam kegiatan pembelajaran. sehingga diharapkan dengan menggunakan metode Advokasi dapat meningkatkan hasil belajar siswa. Berkaitan pengertian dari metode pembelajaran Advokasi, Hamalik (2010:116) menjelaskan sebagai berikut:

Advocacy learning adalah sebagai suatu pendekatan alternatif terhadap pengajaran didaktis didalam kelas yang memberikan kesempatan kepada siswa untuk mempelajari isu-isu sosial dan personal yang berarti melalui keterlibatan langsung dan partisipasi pribadi. Metode belajar ini menuntut para siswa terfokus pada topik yang telah ditentukan sebelumnya dan mengajukan pendapat yang bertalian dengan topik tersebut.

Berdasarkan penjelasan metode Advokasi muncul asumsi bahwa metode Advokasi akan efektif apabila diterapkan pada pembelajaran Al-Qur'an Hadits. Hal tersebut karena materi 
pembelajaran Al-Qur'an Hadits berisi masalah-masalah hukum yang sangat kompleks dan menimbulkan banyak penafsiran. Melalui penerapan metode Advokasi siswa dilatih untuk mencari informasi tentang hukum suatu masalah dan memperdebatkan informasi yang telah diperoleh sehingga akan dapat memperdalam pemahamannya terhadap materi pembelajaran Al-Quran Hadits. Dengan demikian, pemahaman siswa terhadap materi pembelajaran Al-Quran Hadits tidak hanya terbatas pada apa yang disampaikan oleh guru atau pada apa yang tertera dalam buku paket, namun siswa akan memiliki kemampuan untuk memecahkan masalah-masalah ikhtilafiyah pada materi Al-Quran Hadits.

1. Jenis Penelitian

\section{METODE/EKSPERIMEN}

Jenis penelitian ini adalah penelitian tindakan kelas. Kunandar (2008:45) menjelaskan pengertian penelitian tindakan kelas sebagai berikut:

Penelitian tindakan kelas (PTK) didefenisikan sebagai suatu penelitian tindakan (action research) yang dilakukan oleh guru yang sekaligus sebagai peneliti di kelasnya atau bersamasama dengan orang lain dengan jalan merancang, melaksanakan, dan merefleksikan tindakan secara kolaboratif dan partisipatif yang bertujuan untuk memperbaiki atau meningkatkan mutu atau kualitas proses pembelajaran di kelasnya malalui tindakan (treatment) tertentu di dalam suatu siklus.

Penelitian tindakan kelas sering disebut Classroom Action Research (CAR). Arikunto (2010:58) mengatakan, "Penelitian tindakan kelas adalah suatu penelitian yang dilakukan dikelas dengan tujuan memperbaiki atau meningkatkan mutu praktik pembelajaran". Sedangkan menurut Wardhani (2002:4) mengemukakan, "Penelitian tindakan kelas adalah penelitian dilakukan guru di dalam kelasnya sendiri melalui refleksi dengan tujuan memperbaiki kinerjanya sebagai guru, sehingga hasil belajar siswa menjadi meningkat".

\section{Prosedur Penelitian}

Penelitian tindakan kelas dilaksanakan melalui empat tahapan prosedur penelitian meliputi perencanaan tindakan, pelaksanaan tindakan yang diikuti dengan kegiatan observasi, serta refleksi. Apabila diperlukan, pata tahap selanjutnya disusun rencana tindak lanjut. Upaya tersebut dilakukan secara berdaur membentuk suatu siklus. Oleh karena itu, prosedur pelaksanaan tindakan kelas ini dilakukan melalui prosedur berikut:

a. Prasiklus

Tindakan prasiklus merupakan tindakan awal untuk mengetahui kemampuan awal siswa. Rincian kegiatan prasiklus dapat diuraikan sebagai berikut:

1) Perencanaan

Kegiatan perencanaan dilaksanakan untuk mempersiapkan tindakan yang akan dilakukan. Kegiatan-kegaitan pada tahap perencanaan tindakan prasiklus adalah:

a) Menyusun rencana pelaksanaan pembelajaran pada Pokok-Pokok isi Kitab Al-Qur'an sesuai dengan metode pembelajaran yang telah diterapkan di kelas X MA Nurul Huda Kecamatan Buay Madang.

b) Menyusun lembar observasi aktivitas guru dalam pembelajaran.

c) Menyusun lembar obsevasi aktivitas siswa dalam pembelajaran.

d) Menyusun instrumen tes untuk mengetahui hasil belajar siswa sebelum tindakan.

2) Pelaksanaan

Pelaksanaan tindakan prasiklus dilakukan melalui pembelajaran menggunakan rencana pelaksanaan pembelajaran yang telah disusun pada tahap perencanaan yaitu pada materi pembelajaran Pokok-Pokok isi kitab Al-Quran.

3) Observasi 
Observasi tindakan prasiklus dilakukan menggunakan lembar observasi selama kegiatan pembelajaran. Observasi meliputi observasi aktivitas guru mengelola kegiatan pembelajaran dan observasi aktivitas siswa mengikuti kegiatan pembelajaran. Observasi guru dilakukan menggunakan lembar observasi guru yang diisi oleh kolaborator, sedangkan observasi aktivitas siswa dilakukan menggunakan lembar observasi aktivitas siswa yang diisi oleh peneliti yang berperan ganda yaitu sebagai guru sekaligus sebagai observer. Lebih jelasnya lembar observasi yang digunakan dapat dilihat pada lampiran.

4) Refleksi

Kegiatan refleksi dilakukan setelah kegiatan pembelajaran selesai bersama kolaborator. Refleksi dilaksanakan untuk mengetahui berbagai kelebihan maupun kelemahan yang diketemukan pada tindakan prasiklus. Kelebihan yang ditemukan akan dipertahankan dan sebagai acuan pelaksanaan tindakan siklus, sedangkan kelemahan yang ditemukan akan dijadikan sebagai dasar perencanaan tindakan siklus 1 .

\section{b. Rincian Kegiatan Siklus 1}

Tindakan siklus 1 dilaksanakan berdasarkan kelemahan yang diketemukan pada tindakan prasiklus. Siklus 1 dilaksanakan melalui empat tahapan sebagai berikut:

1) Perencanaan

Perencanaan tindakan siklus 1 didasarkan pada kelemahan yang diketemukan pada hasil refleksi tindakan prasiklus. Hal-hal yang direncanakan meliputi:

a) Menyusun rencana tindakan perbaikan pembelajaran pada poko-pokok isi kitab AlQur'an dimakan melalui penerapan metode Advokasi.

b) Menyusun lembar observasi aktifitas guru dalam pembelajaran menggunakan metode Advokasi.

c) Menusun lembar observasi aktivitas siswa dalam mengikuti kegiatan pembelajaran menggunakan metode Advokasi.

d) Menyusun instrumen tes untuk mengetahui hasil belajar siswa setelah tindakan perbaikan melalui penerapan metode Advokasi.

e) Menetapkan target yang hendak dicapai yaitu aktifitas guru mencapai $90 \%$, aktifitas belajar siswa mencapai $90 \%$ dan ketuntasan belajar siswa mencapai $90 \%$.

\section{2) Pelaksanaan}

Pelaksanaan tindakan siklus 1 dilakukan melalui kegiatan pembelajaran satu kali pertemuan dengan alokasi waktu 2 × 40 menit sesuai dengan rencana pelaksanaan perbaikan pembelajaran yang telah disusun selama kegiatan perencanaan. Pembelajaran dilakukan oleh peneliti sebagai guru dibantu kolaborator sebagai observer. Lebih rincinya pelaksanaan tindakan siklus 1 dapat dilihat pada lampiran pelaksanaan perbaikan pembelajaran siklus 1 .

3) Observasi

Observasi dilaksanakan bersamaan dengan tindakan pembelajaran. Masalah yang diamati adalah aktifitas guru dalam mengelola kegiatan pembelajaran dan aktifitas siswa mengikuti kegiatan pembelajaran. Aspek observasi aktifitas guru dan aktifitas siswa sama dengan observasi tindakan prasiklus.

4) Refleksi

Kegiatan akhir tindakan siklus 1 adalah melakukan refleksi terhadap tindakan yang telah dilaksanakan. Refleksi dilakukan dengan menganalisis seluruh kegiatan siklus untuk menemukan berbagai kelebihan atau keberhasilan serta kelemahan atau kendala yang dihadapi pada tindakan siklus 1 . Kelemahan yang diketemukan akan dijadikan sebagai dasar pelaksanaan tindakan siklus 2 .

\section{c. Rincian Kegiatan Siklus 2 dan Seterusnya}

Penelitian tindakan kelas merupakan bentuk penelitian yang dilakukan melalui siklus-siklus berkelanjutan. Kegiatan siklus dianggap selesai apabila target yang ditentukan telah tercapai. 
Tidak ada batasan jumlah siklus yang akan dilaksanakan. Siklus 1 merupakan tindakan yang dilakukan berdasarkan kelemahan tindakan prasiklus. Siklus 2 merupakan tindakan yang dilakukan untuk memperbaiki kelemahan tindakan siklus 1. Oleh karena itu, rincian kegiatan siklus 2 akan dapat disusun apabila tindakan siklus 1 telah selesai dilaksanakan dan rincian siklus 3 akan dapat disusun apabila tindakan siklus 2 telah dilaksanakan

\section{d. Subjek dan Objek Penelitian}

Kunandar (2011:16) mengatakan, "Objek penelitian tindakan kelas adalah seluruh kegiatan maupun benda yang terdapat dalam kelas sebagai pusat sasaran penelitian". Seluruh aktivitas akademik pada kelas penelitian. Subjek dari penelitian ini adalah siswa kelas X MA Nurul Huda Kecamatan Buay Madang Kabupaten OKU Timur berjumlah 27 siswa dengan perincian 9 siswa laki-laki dan 18 siswa perempuan.

\section{Teknik Pengumpulan Data}

\section{a. Observasi}

Obervasi pada penelitian ini dilaksanakan bersamaan tahap pelaksanaan tindakan yang meliputi observasi aktivitas belajar siswa dan observasi aktivitas guru dalam mengelola kegiatan pembelajaran. Observasi aktivitas belajar siswa dilakukan oleh guru yang berperan ganda yaitu sebagai guru, peneliti serta observer. Observasi aktivitas guru dalam mengelola kegiatan pembelajaran dilakukan oleh kolaborator atau teman sejawat menggunakan lembar observasi. Observasi aktivitas guru dilaksanakan menggunakan lembar penilaian kinerja guru (LPKG) oleh teman sejawat sebagai observasi. Adapun lembar observasi terhadap aktivitas siswa dilaksanakan untuk mengetahui tingkat keaktifan siswa mengikuti pelajaran. Observasi ini dilaksanakan lembar observasi siswa. Adapun lembar penilaian kinerja guru sebagai instrumen observasi aktivitas guru dapat dilihat pada table 3.2 berikut:

Tabel .1

Lembar Observasi Guru

\begin{tabular}{|c|c|c|c|}
\hline No & Aspek Observasi & \multicolumn{2}{|c|}{ Skor } \\
\hline 1 & $\begin{array}{l}\text { Guru menjelaskan prosedur kegiatan pembelajaran yang akan } \\
\text { dilaksanakan }\end{array}$ & $\sqrt{ }$ & \\
\hline 2 & $\begin{array}{l}\text { Guru penjelasan tentang materi pembelajaran sebagaimana } \\
\text { terdapat pada ringkasan materi }\end{array}$ & $\sqrt{ }$ & \\
\hline 3 & $\begin{array}{l}\text { Guru memilih suatu topik debat berdasarkan pertimbangan } \\
\text { aspek kebermaknaannya, tingkatan siswa, relevansinya dengan } \\
\text { kurikulum, dan minat para siswa }\end{array}$ & $\sqrt{ }$ & \\
\hline 4 & $\begin{array}{l}\text { Guru membimbing setiap regu mencari informasi dari berbagai } \\
\text { sumber tentang topik debat yang telah diberikan }\end{array}$ & & $\sqrt{ }$ \\
\hline 5 & $\begin{array}{l}\text { Guru membimbing setiap regu untuk mendiskusikan informasi } \\
\text { yang diperoleh sebagai bentuk persiapan debat }\end{array}$ & & $\sqrt{ }$ \\
\hline 6 & $\begin{array}{l}\text { Guru memberikan petunjuk dan asistensi kepada siswa untuk } \\
\text { membantuk menyiapkan debat }\end{array}$ & $\sqrt{ }$ & \\
\hline 7 & $\begin{array}{l}\text { Guru memandu dan mengkondisikan siswa dalam melaksanakan } \\
\text { debat }\end{array}$ & $\sqrt{ }$ & \\
\hline 8 & $\begin{array}{l}\text { Guru memberikan kesimpulan dengan mengambil pendapat } \\
\text { setiap kelompok yang telah diperdebatkan }\end{array}$ & $\sqrt{ }$ & \\
\hline 9 & $\begin{array}{l}\text { Guru memberikan evaluasi untuk mengetahui tingkat } \\
\text { pemahaman siswa terhadap materi pembelajaran }\end{array}$ & $\sqrt{ }$ & \\
\hline 10 & $\begin{array}{l}\text { Guru menutup kegiatan pembelajaran dengan memberikan } \\
\text { refleksi dan penguatan }\end{array}$ & $\sqrt{ }$ & \\
\hline
\end{tabular}




\begin{tabular}{|c|c|}
\hline Jumlah Skor & \\
\hline Rata-rata $=\frac{\text { Perolehan Skor }}{\text { Aspek Penilaian }}=-\quad=$ & \\
\hline$\%=\frac{\text { Perolehan Skor }}{\text { Skor Maksimal }} \times 100=-\times 100=$ & \\
\hline
\end{tabular}

Sumber: Danim (2010:138)

Selain observasi terhadap aktivitas guru dalam pembelajaran, observasi juga dilakukan terhadap aktifitas siswa mengiuti kegiatan pembelajaran. Observasi dilakukan untuk mengetahui tingkat efekaktifitas metode pembelajaran deduktif dalam mengaktifkan siswa mengikuti kegiatan pembelajaran. Aspek observasi aktifitas siswa dalam pembelajaran silakukan dengan menggunakan lembar observasi sebagai berikut:

Tabel. 2

Lembar Observasi Aktivitas Belajar Siswa

\begin{tabular}{|c|l|c|c|c|c|c|c|c|c|c|c|c|c|}
\hline \multirow{2}{*}{ No } & \multirow{2}{*}{ Nama siswa } & \multicolumn{3}{|c|}{ Perhatian } & \multicolumn{3}{|c|}{ partisipasi } & \multicolumn{3}{|c|}{ presentasi } \\
\cline { 3 - 12 } & & $\mathbf{1}$ & $\mathbf{2}$ & $\mathbf{3}$ & $\mathbf{4}$ & $\mathbf{1}$ & $\mathbf{2}$ & $\mathbf{3}$ & $\mathbf{4}$ & $\mathbf{1}$ & $\mathbf{2}$ & $\mathbf{3}$ & $\mathbf{4}$ \\
\hline $\mathbf{1}$ & Eka Saputri & & & & & & & & & & & & \\
\hline $\mathbf{2}$ & Dst & & & & & & & & & & & & \\
\hline & Perolehan & & & & & & & & & & & & \\
\hline & Jumlah & & & & & & & & & & & \\
\hline
\end{tabular}

Keterangan:

Aspek yang dimulai $=3$

Skor maksimal $=4 \times 3=12$

Cara perhitungan $=\frac{\text { Perolehan Skor }}{\text { Skor Maksimal }} \times 100$

b. Tes

Menurut Toyibnafis ( 2008:207) mengatakan " Tes adalah seperangkat stimulasi diberikan kepada seseorang dengan maksud untuk untuk mendapatkan jawaban-jawaban yang dijadikan penetapan skor angka". Tes pada umun ya digunakan untuk menilai dan mengukur hasil belajar siswa berkenaan dengan penguasaan bahan pengajaran sesuai dengan tujuan pembelajaran. Tes sebagai alat pengumpul informasi atau data, tes harus dirancang secara khusus. Kekhususan tes terlihat dari bentuk soal tes yang digunakan, jenis pertanyaan, rumusan pertanyaan yang diberikan, dan pola jawabannya harus dirancang menurut kriteia yang telah ditetapkan.

Tes pada penelitian ini dilakukan setiap akhir pembelajaran siklus. Soal tes yang diberikan berbentuk pilihan ganda sebanyak 10 nomor untuk setiap siklusnya. Tes dilaksanakan untuk mengetahui ada tidaknya peningkatan hasil belajar setelah tindakan siklus dan mengetahui efektivitas kegiatan pembelajaran yang telah dilaksanakan.

\section{Teknik Analisis Data}

Teknik analisa data adalah teknik yang digunakan menganalisa yang diperoleh dari hasil penelitian. Data yang sudah terkumpul kemudian diolah yakni dianalisis diinterpretasikan dan disimpulkan. Teknik analisa data yang digunakan dalam penelitian ini adalah teknik analisa data 
statistik. Analisis statistik adalah dalam menganalisis suatu data menggunakan dasar teknik dan tata kerja statistik, sedangkan non statistik adalah analisis data dengan menggunakan metode kualitatif. Secara terperinci teknik analisis data yang digunakan pada penelitian ini meliputi analisis data hasil observasi dan analisis data hasil tes.

Obervasi dilakukan untuk mengetahui tingkat aktivitas siswa dan guru pada kegiatan pembelajaran. Untuk mengetahui aktivitas selama proses pembelajaran maka dilakukan pengamatan, aspek yang diamati sesuai dengan lembar observasi yang dibuat. Didalam lembar observasi dicantumkan komponen-komponen aktivitas belajar siswa. Jika komponen-komponen aktivitas belajar muncul pada deskriptor yang diberikan, maka observer diminta membubuhkan tanda cek $(\sqrt{ })$ pada kolom yang sesuai. Selanjutnya observer memberikan skor masing-masing komponen yang sudah diberi tanda cek $(\sqrt{ })$.

Skor yang diberikan adalah skor 5 jika semua deskriptor muncul, skor 4 jika tiga deskriptor muncul, skor 3 jika dua deskriptor muncul, skor 2 jika satu deskriptor muncul, dan skor 1 jika tidak ada deskriptor muncul. Adapun persentase rata-rata skor dihitung sebagai berikut:

Prosentase Rata-rata Skor $=\frac{\text { Skor yang Diperoleh }}{\text { Skor Maksimal }} \times 100$ (Suryabrata, 2004:135).

Hasil observasi dalam \% dapat dikonversikan ke dalam data kualitatif untuk menentukan kategori keaktifan siswa dan aktivitas guru dalam pembelajaran terlihat pada tabel 3.2 berikut:

Tabel. 3

Kategori Hasil Observasi

\begin{tabular}{|c|c|}
\hline Skor (\%) & Kategori \\
\hline $76-100$ & Tinggi \\
$51-75$ & Sedang \\
$26-50$ & Rendah \\
$0-25$ & Sangat Rendah \\
\hline
\end{tabular}

Sumber: Suyanto (2007:22)

Data-data hasil tes pada penelitian tindakan kelas dianalisis tingkat ketuntasan belajar siswa yaitu sesuai dengan Kriteria Ketuntasan Minimal pembelajaran Al-Qur'an Hadits kelas X MA Nurul Huda Kecamatan Buay Madang yaitu 70. Jumlah siswa yang memperoleh nilai sesuai Kreteria Ketuntasan Minimal dihitung dan diprosentasekan menggunakan rumus berikut:

$$
\mathrm{HA}=\frac{\mathrm{f}}{\mathrm{n}} \mathrm{x} 100
$$

Keterangan:

HA = Hasil Akhir.

$\mathrm{f}=$ Jumlah siswa yang mencapai KKM.

$\mathrm{n}=$ Jumlah siswa seluruhnya.

Analisis data tersebut diperoleh berdasarkan hasil tindakan pada setiap siklus. Hasil tindakan pada setiap siklus dibandingkan dengan hasil tes awal untuk mengetahui presentase peningkatan hasil belajar siswa. Setiap siklus diupayakan adanya peningkatan-peningkatan perolehan skor hasil belajar siswa untuk menunjukkan efektivitas pembelajaran. Ketuntasan yang hendak dicapai adalah $90 \%$ dari jumlah siswa keseluruhan telah mencapai KKM ditetapkan yaitu 70. Interpretasi prosentase ketuntasan belajar siswa dilakukan menggunakan tabel 3.3 berikut:

Tabel. 4

Kriteria Ketuntasan Hasil Belajar Siswa 


\begin{tabular}{|c|c|}
\hline Skor (\%) & Kategori \\
\hline $76-100 \%$ & Tinggi \\
$51-75 \%$ & Sedang \\
$26-50 \%$ & Rendah \\
$0-25 \%$ & Sangat Rendah \\
\hline
\end{tabular}

Sumber: Suyanto (2007:22)

\begin{abstract}
HASIL DAN PEMBAHASAN
Hasil

Masalah diangkat dalam penelitian ini adalah rendahnya hasil belajar mata pelajaran Al-Qur'an Hadits siswa. Setelah masalah penelitian diketahui, dilakukan analisis penyebab terjadinya masalah dan diketahui bahwa masalah muncul karena pembelajaran Al-Qur'an Hadits hanya dilaksanakan secara verbalis. Selain itu, masalah muncul akibat kurangnya waktu bagi siswa berlatih menganalisis dan merumuskan permasalahan sehingga pengetahuan siswa hanya bersifat teoretis. Oleh karena itu, tindakan akan dilakukan dengan metode Advokasi.
\end{abstract}

\title{
Pembahasan
}

Secara keseluruhan hasil dari tindakan dapat dideskripsikan sebagai berikut:

1. Hasil Belajar Mata Pelajaran Al-Qur'an Hadits Materi Pembelajaran Pokok-Pokok Isi Kitab Al-Qur'an Siswa Sebelum Penerapan Metode Advokasi di Kelas X IPA MA Nurul Huda Kecamatan Buay Madang Kabupaten OKU Timur

Pelaksanaan tindakan prasiklus dilakukan melalui pembelajaran menggunakan rencana pelaksanaan pembelajaran yang telah disusun pada tahap perencanaan yaitu pada materi pembelajaran yaitu pengertian, Aqidah, Hukum, Sejarah, Muamalah dan Ibadah, Akhlaq, Sains dan teknologi. Pembelajaran dilakukan oleh peneliti yang bertindak sebagai guru dengan dibantu kolaborator sebagai observer. Pembelajaran prasiklus dilakukan satu kali pertemuan dengan alokasi waktu 2 × 40 menit.

\section{Prosentase aktivitas guru dalam pembelajaran prasiklus adalah rendah.}

Prosentase hasil observasi aktivitas guru dalam pembelajaran sebesar $32,50 \%$ berada pada interval 26 - 50\% sehingga diinterpretasikan bahwa aktivitas guru dalam kegiatan pembelajaran prasiklus adalah rendah. Aktivitas belajar siswa kelas X IPA MA Nurul Huda Kecamatan Buay Madang Kabupaten OKU Timur adalah rendah. Prosentase aktivitas belajar siswa secara klasikal sebesar $28,41 \%$ berada pada interval $26-25 \%$ yang berada pada kategori rendah.

Rendahnya aktivitas guru dan siswa selama kegiatan pembelajaran berimplikasi pada rendahnya hasil belajar siswa. Berdasarkan hasil tes pada tindakan prasiklus diperoleh nilai total siswa sebesar 1430 dengan nilai rata-rata siswa hanya mencapai 52,96, jumlah siswa mencapai KKM sebanyak 7 siswa atau $14,64 \%$, siswa tidak mencapai ketuntasan sebanyak 20 orang atau $80,00 \%$. Ketuntasan belajar sebesar $25,92 \%$ berada pada interval $1-25$ yang berarti ketuntasan belajar siswa adalah sangat rendah. Oleh karena itu, perlu dilaksanakan tindakan untuk memperbaiki proses serta hasil belajar siswa yang dalam hal ini melalui penerapan metode Advokasi dalam tindakan penelitian kelas.

3. Hasil Belajar Mata Pelajaran Al-Qur'an Hadits Materi Pembelajaran Pokok-Pokok Isi Kitab Al-Qur'an Siswa Setelah Penerapan Metode Advokasi di Kelas X IPA MA Nurul Huda Kecamatan Buay Madang Kabupaten OKU Timur

Pada setiap akhir kegiatan pembelajaran siklus dilakukan evaluasi untuk mengetahui hasil belajar mata pelajaran Al-Qur'an Hadits siswa. Evaluasi dilaksanakan dengan memberikan soal-soal tertulis berbentuk pilihan ganda sebanyak 10 nomor. Seluruh kegiatan tes setiap siklus diikuti oleh seluruh siswa kelas X IPA MA Nurul Huda Kecamatan Buay Madang Kabupaten OKU Timuryang berjumlah 27 orang siswa. Hasil tes mata pelajaran Al-Qur'an Hadits siswa setelah tindakan siklus 1 
adalah memperoleh nilai total 1670 dengan nilai rata-rata siswa mencapai 61,85 , jumlah siswa mencapai KKM sebanyak 11 siswa atau 41,91\%, siswa tidak mencapai ketuntasan sebanyak 13 orang atau $60,09 \%$. Prosentase ketuntasan belajar siswa setelah tindakan siklus 1 sebesar $40,41 \%$. Ketuntasan belajar siswa diketahui bahwa hasil belajar Al-Qur'an Hadits siswa kelas X IPA MA Nurul Huda Kecamatan Buay Madang Kabupaten OKU Timur setelah tindakan siklus 1 melalui penerapan metode Advokasi adalah rendah. Pelaksanaan tindakan siklus 1 dapat meningkatkan hasil belajar AlQur'an Hadits siswa sebesar $27,27 \%$ dari tindakan prasiklus.

Kegiatan penelitian siklus 1 ditindaklanjuti dengan melaksanakan tindakan siklus 2. Pada akhir kegiatan tindakan siklus 2 dilakukan evaluasi untuk mengetahui hasil belajar Al-Qur'an Hadits siswa. Hasil evaluasi menunjukkan skor total yang diperoleh siswa adalah 1980 dengan nilai rata-rata siswa mencapai 73,33, jumlah siswa mencapai KKM sebanyak 20 siswa atau 72,73\%, siswa tidak mencapai ketuntasan sebanyak 7 orang atau $27,27 \%$. Prosentase ketuntasan belajar siswa pada tindakan siklus 2 sebesar $74.07 \%$. Hal tersebut menunjukkan bahwa hasil belajar mata pelajaran AlQur'an Hadits siswa pada tindakan siklus 3 adalah tinggi. Meskipun telah terjadi peningkatan hasil belajar siswa yang signifikan, namun target penelitian sebesar $90 \%$ dari jumlah siswa seluruhnya mencapai ketuntasan belum tercapai, sehingga penelitian harus dilanjutkan pada tindakan siklus berikutnya yaitu siklus 3 .

Hasil evaluasi tindakan siklus 3 menunjukkan nilai total yang diperoleh siswa adalah 2410 dengan nilai rata-rata siswa mencapai 89,25, jumlah siswa mencapai KKM sebanyak 27 siswa atau $100 \%$ dan telah tidak terdapat siswa yang tidak mencapai ketuntasan. Data tersebut menunjukkan bahwa target $90 \%$ siswa dapat mencapai ketuntasan telah tercapai sehingga tidak diperlukan siklus lanjutan. Prosentase ketuntasan belajar siswa pada tindakan siklus 3 sebesar $100 \%$. Hal tersebut menunjukkan bahwa hasil belajar mata pelajaran Al-Qur'an Hadits siswa pada tindakan siklus 3 adalah tinggi. Prosentase ketuntasan belajar siswa sebesar $100 \%$ telah memenuhi target yang ditetapkan yaitu $90 \%$ dari jumlah siswa seluruhnya telah mencapai ketuntasan.

\section{Peningkatan Hasil Belajar Mata Pelajaran Al-Qur'an Hadits Materi Pokok-Pokok Isi Kitab Al- Qur'an Melalui Penerapan Metode Advokasi Siswa Kelas X IPA MA Nurul Huda Kecamatan Buay Madang Kabupaten OKU Timur}

Setelah diadakan penelitian yang terdiri dari tiga siklus dan ditempuh dalam 3 kali pertemuan dengan alokasi waktu 6 jam pelajaran diperoleh hasil yang cukup memuaskan. Penerapan metode Advokasi secara nyata dapat meningkatkan aktivitas guru dalam pembelajaran, aktivitas belajar siswa serta hasil belajar Al-Qur'an Hadits siswa yang ditandai dengan meningkatnya ketuntasan hasil belajar siswa. Kesimpulan akhir penelitian ini adalah penerapan metode Advokasi dapat meningkatkan hasil belajar mata pelajaran Al-Qur'an siswa kelas X IPA MA Nurul Huda Kecamatan Buay Madang Kabupaten OKU Timur setiap siklusnya rata-rata 24,39\%.

\section{PENUTUP}

Berdasarkan hasil penelitian yang telah dipaparkan dapat disimpulkan sebagai berikut:

1. Hasil belajar mata pelajaran Al-Qur'an Hadits materi pembelajaran Pokok-pokok isi Kitab AlQur'an siswa sebelum penerapan metode Advokasi di kelas X IPA MA Nurul Huda Kecamatan Buay Madang Kabupaten OKU Timur adalah sangat rendah yaitu dari 27 siswa hanya terdapat 7 siswa atau $14,64 \%$, siswa tidak mencapai ketuntasan sebanyak 20 orang atau $800,00 \%$.

2. Hasil belajar mata pelajaran Al-Qur'an Hadits materi Pokok-pokok isi Kitab Al-Qur'an siswa setelah penerapan metode Advokasi di kelas X IPA MA Nurul Huda Kecamatan Buay Madang Kabupaten OKU Timur termasuk kategori tinggi atau baik dengan indikator $100 \%$ siswa dapat mencapai ketuntasan setelah tindakan siklus 3 .

3. Penerapan metode Advokasi dapat meningkatkan hasil belajar mata pelajaran Al-Qur'an Hadits siswa kelas X IPA MA Nurul Huda Kecamatan Buay Madang Kabupaten OKU Timur dengan indikator:

a. Aktivitas guru dalam pembelajaran termasuk kategori baik yaitu mencapai $95 \%$ pada siklus 3 
dimana semula mencapai $72,50 \%$ pada siklus $2,45 \%$ pada siklus 1 , dan $32,50 \%$ pada tindakan prasiklus.

b. Aktivitas siswa dalam pembelajaran masuk kategori baik yaitu mencapai $93,56 \%$ pada siklus 3 dimana semula $67,42 \%$ pada siklus $2,46,97$ pada siklus 1 dan $28,40 \%$ pada tindakan prasiklus.

4. Ketuntasan belajar siswa mencapai $100 \%$ dimana semula $14,64 \%$ pada prasiklus, $40,91 \%$ pada siklus 1 , dan $72,73 \%$ pada siklus 2 .

Secara umum pelaksanaan penelitian dapat berjalan secara lancar. Penelitian dapat dilaksanakan sesuai jadwal serta dapat memenuhi target yang telah ditetapkan. Meskipun demikian, pelaksanaan tindakan tidak luput dari berbagai kendala sebagai bentuk keterbatasan penelitian. Untuk itu kritik dan saran sangat diharapkan.

\section{UCAPAN TERIMAKASIH}

Ucapan terimakasih ditujukan kepada institusi resmi atau perorangan sebagai penyandang dana, atau yang telah memberikan kontribusi lain dalam penelitian. Ucapan terimakasih dilengkapi dengan nomor surat kontrak penelitian.

\section{DAFTAR PUSTAKA}

Al-Maraghi, Ahmad Musthafa Ibn Musthafa ibn Muhammad ibn Abd al-Mun'im al-Qadhi. t.t. Tafsir AlMaraghi. Terjemahan Abu Ahmadi Juz 16. Surabaya: Almaktab.

Arikunto, Suharsimi. 2010. Prosedur Penelitian;Suatu Pendekatan Praktik. Jakarta: Rineka Cipta.

Djamarah, Syaiful Bahri. 2008. Psikologi Belajar. Jakarta: Rineka Cipta.

Hamalik, Oemar. 2010. Proses Belajar Mengajar. Jakarta: Bumi Aksara.

Kunandar. 2008. Langkah Mudah Penelitian Tindakan Kelas Sebagai Pengembangan Profesi Guru. Jakarta: Raja Grafindo Perada.

Madrasah Aliyah Nurul Huda 2013. Profil MA Nurul Huda. Sukaraja: MA NH.

Madrasah Aliyah Nurul Huda 2013. Kalender Pendidikan . Sukaraja: MA NH.

Slameto. 2010. Belajar dan Faktor-faktor yang Mempengaruhinya. Jakarta: Rineka Cipta.

Suyanto. 2007. Desain Pelaksanaan Penelitian Tindakan Kelas. Bandung: Yuma Pustaka.

Thobroni, Muhammad. 2011. Belajar dan Pembelajaran: Pengembangan Wacana dan Praktik Pembelajaran dalam Pembangunan Nasional. Yogyakarta: Ar-Ruz Media.

Utsman, Abdulah. 2013. Dasar-dasar Agama Islam. Jakarta: Kencana Media.

Utsman, Muhammad Uzer. 2011. Upaya Optimalisasi Kegiatan Belajar Mengajar. Bandung: Remaja Rosdakarya.

Walgito, Bima. 2007. Evaluasi Pembelajaran. Jakarta: Prestasi Pustaka.

Wardhani, Igak. 2008. Penelitian Tindakan Kelas. Jakarta: Universitas Terbuka. 